
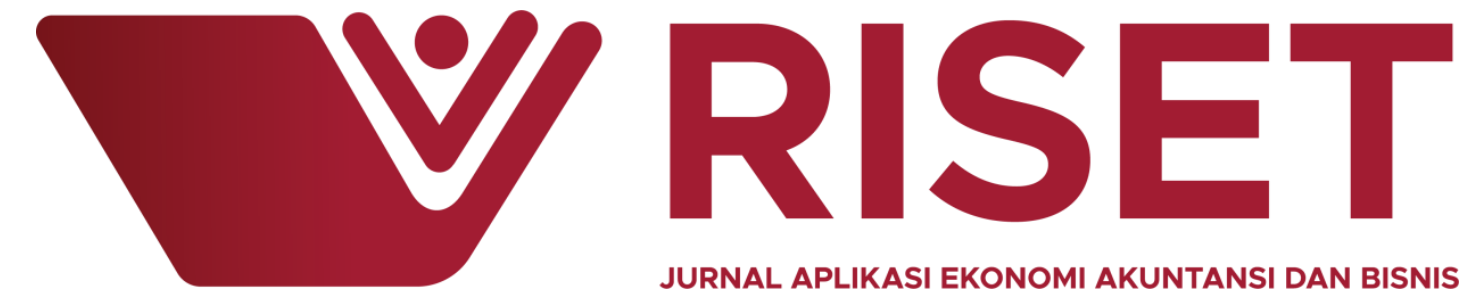

JURNAL APLIKASI EKONOMI AKUNTANSI DAN BISNIS

\title{
THE EFFECT OF TAX EXAMINATION EFFECTIVENESS ON TAX AVOIDANCE WITH POLITICAL CONNECTION MODERATION
}

\author{
Roshid Andru Mustaqiim ${ }^{1)}$, Nurhidayati ${ }^{2)}$ \\ ${ }^{1)}$ Directorate General of Taxation , ${ }^{2)}$ State Finance Polytechnic STAN
}

\section{INFO ARTICLES}

The Effect Of Tax

Examination

Effectiveness On Tax

Avoidance With

Political Connection

Moderation

Submitted:

29 - August - 2020

Revised:

12 - September - 2020

Accepted:

25 - September - 2020

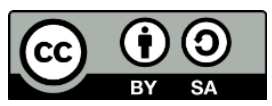

\begin{abstract}
The self-assessment system in which the taxpayer performs the calculation, payment, and tax reporting by the taxpayer itself risks tax avoidance practices. To minimize this risk, the Directorate General of Taxation carries out law enforcement in the framework of supervision through tax audit activities. This study aims to analyze the effect of the effectiveness of the inspection on tax avoidance practices by using a moderated political connection because it is suspected that companies with a political link tend to be more aggressive in terms of tax planning. This study uses panel data of companies listed on the Indonesia Stock Exchange from 2016 to 2018. The study results conclude that tax audits effectiveness has a significant effect on tax avoidance practices, which means that the more influential the tax audit activities are, the lower the tax avoidance level.
\end{abstract}

Keywords: tax audit, tax avoidance, political connection

Email : $\underline{\text { roshidandru@gmail.com }}^{1)} \cdot \underline{\text { nurhidayati@pknstan.ac.id }}^{2)}$

\section{INTRODUCTION}

Tax revenue is closely related to the level of taxpayer compliance. Andreoni et al. (1998, 822), in a study in the United States, said that taxpayers' non-compliance significantly would reduce tax revenues. Meanwhile, according to Hutagaol et al. (2007, 186), compliance is a fundamental problem faced in almost all countries implementing tax systems. Based on the DGT Annual Report 2015, formal compliance for the submission of Annual Tax Returns (SPT) is around $60.27 \%$ of the total number of Taxpayers (WP) Taxpayers. The number of taxpayers who delivered the SPT consisted of 676,405 corporate taxpayers, 837,228 non-employee individual taxpayers (OP), and 9,431,934 Employee OPs. It means that the level or ratio of formal compliance for corporate taxpayers has only reached $57.09 \%$, non-employee taxpayers, $40.75 \%$, and employee taxpayers $63.22 \%$. It is increasingly concerning, with only $1,172,018$ taxpayers having the status of paying taxpayers. John Hutagaol et al. $(2007,186)$ quotes Andreoni et al. (1998, 818), states based on various studies. The compliance issues can be seen in terms of public finance, law enforcement, organizational structure, workforce, ethics (code of conduct), or a combination of all these aspects. 
The low level of taxpayer compliance, especially corporate taxpayers, is one of the consequences and risks of the taxation system implemented in a country (Simon James 1999, 731). According to Mardiasmo (2011, 7), there are three types of tax collection systems in Indonesia. The first system is the self-assessment system, which gives the taxpayer the authority to calculate, pay, and report the taxpayers' taxes themselves. Another technique is the official assessment system, where the power to determine the amount of tax owed by the taxpayer lies with the tax authorities. This Directorate General of Taxes and the withholding system lead to the authority to determine the amount of tax owed lies with a third party (neither the DGT nor the taxpayer concerned).

Based on the law mandate, the Directorate General of Taxes is given authority to enforce the law to monitor the self-assessment system's implementation and the withholding system. One of the very strategic roles in monitoring activities is a tax audit. It is in line with research by J. Alm et al. $(1992,36)$, which states that one of the determinants that affect the level of compliance is audit rates. The higher the probability of a tax audit carried out, the more obedient people will be.

The Directorate General of Taxes is faced with limited tax audit activities; there are challenges for corporate taxpayer transactions that are increasingly complex with tax avoidance. As an illustration, the tax auditor's practical resources are not proportional to the number of taxpayers. The author's latest data shows that the number of tax auditors is 4,552 people, while taxpayers are 30 million taxpayers. This results in the overall Audit Coverage Ratio (ACR) in Indonesia in 2016 relatively low, namely around 2\% for corporate taxpayers and $0.36 \%$ for individuals (DGT 2016 Annual Report). On the one hand, the strategic role of auditing should be optimized to increase compliance ( $\mathrm{J}$. Alm 1992, 36), on the other hand, to reduce tax avoidance practices through the deterrent effect, particularly by companies (Hoopes 2012, 1632).

In running its business, the company's primary goal is to get maximum profit with minimum expenses. One of the most costs avoided by company managers is the payment of taxes. The level of tax payments depends on the company's profit, so in general, the higher the profit generated, the higher the tax paid. Tax is seen as an expense that must be deducted. One way of reducing the tax burden is to do tax avoidance.

Tax avoidance is a deliberate attempt by the company to reduce tax obligations either through ways and strategies of both legal and illegal (Lee, Dobiyanski, Minton 2015, 21). Dyreng et al. $(2008,62)$ state that companies that do tax avoidance are not always wrong because many provisions in taxes encourage companies to reduce taxes, coupled with unclear legal boundaries (a gray area), especially for complex transactions. Although tax avoidance often harms the state because it reduces revenue, the government, in some cases, cannot impose sanctions because, legally, there are no rules violated. The lawful nature of tax avoidance makes it difficult for the government to impose sanctions, even when there are indications that the company will implement a tax avoidance scheme. McGuire et al. $(2012,976)$ state that tax avoidance is a company management tool for tax saving by diverting the government's resources to shareholders so that company value increases. The statement that management plays an essential role in determining corporate tax avoidance schemes is strengthened by research conducted by Dyreng et al. $(2008,79)$ and Budiman $(2012,32)$. Leuz and Gee $(2006,1)$ state that companies must seek and take advantage of opportunities in the business environment in developing a competitive strategy, one of which is through political connections.

Faccio $(2006,369)$ states that companies' encouragement to have political connections gets special attention from economic observers because of indications of preferential treatment from the government, especially for companies directly owned by officials or influential people positions in government. Companies are said to have 
political connections if at least one of the principal shareholders (people who have at least 10 percent of the total voting rights). Otherwise, one of the leaders (CEO, president, vice president, chairman, or secretary) is a parliament member, minister, or relationship with a politician or political party (Faccio 2006, 370). Kim and Zhang $(2016,98)$ connect corporate political connections to tax aggressive actions and find that this study's results are more or less the same. Companies with political connections will receive protection from the government, have easy access to obtaining capital loans, or gain special permits in the government administration system, thus making companies more aggressive in implementing tax planning.

Concerning tax obligations, political connections also allow companies to influence on going law enforcement processes. Research previously conducted by Lin, Mills, and Zhang $(2017,32)$ in China shows that corporate executives' attachment to politics significantly affects tax audits' effectiveness in reducing corporate tax avoidance.

\section{LITERATURE REVIEW}

\section{Agency Theory}

Agency theory defines an agency relationship in the form of " a contract under which one or more person (the principals) engage another (the agent) to perform some service on their behalf which involves delegating some decisions making authority to the agent." (Jensen and Meckling 1976, 5).

The statement explains that the agency relationship is defined as a contract between the manager (agent) and the owner (principal) where the owner (principal) delegates a portion of the authority to the manager to carry out company activities and the power to make decisions. Agency theory assumes that each individual is motivated solely by his interests, causing conflict between the owner and the manager, which causes the manager to act inconsistently with the owner's interests. Managers are given sufficient incentives for managers to work in owners' or shareholders' interests and incur costs to limit managers' deviations in bonding costs and monitoring costs. The manager's decision to carry out tax avoidance activities is one of the agency problems. Tax avoidance from tax avoidance includes inexpensive funding sources for companies, and the benefits of tax avoidance are quite large economically (CS Armstrong, Blouin, and Larcker 2012, 4). However, tax avoidance is aggressive and can be followed by the company's cost, both seen as fines, penalties or legal fees, and the expenses that do not look like a significant risk and reputation of the company (C. Armstrong et al. 2015, 4).

\section{Tax Avoidance Theory}

The theoretical analysis of how individuals avoid taxes was described in 1972 by Allingham and Sandmo, referring to research on taxes and individual decision making in an uncertainty, previously described by Mossin (1968), Stiglitz (1969), and Becker (1968). The probability of detection is one of the variables raised in Allingham and Sandmo (1972, 331). Individuals' tendency to avoid taxes will increase along with a decrease in the perception of the possibility of auditing by tax authorities. In Lee, Dobiyanski, and Minton $(2015,21)$, taxation (tax avoidance) is defined as a deliberate effort by the company to reduce tax obligations either legally or illegally. Another definition from Arnold $(2008,3)$ states that tax avoidance is a transaction scheme that reduces the tax burden that can only be recognized if the transaction has economic substance, and contains considerations other than tax and is not solely done for tax avoidance. Tax savings of tax avoidance activity are sources of funding for the company as an alternative to further funding from a third party, even though its reputation is 
risky. Tax evasion is often associated with tax planning (tax planning), both of which use the same means that are legal to reduce or even eliminate the tax liability. Tax planning is considered standard, but tax evasion is generally regarded as illegal in many countries. The boundaries between tax avoidance and tax planning are often unclear. Tax evasion by exploiting loopholes in taxation regulations to violate the law makes this issue an ongoing discussion issue. The discussion regarding the extent to which the limits are allowed to distinguish acceptable tax planning practices from unacceptable tax avoidance is a lengthy debate. It is often resolved through proceedings to the highest court. From a tax policy point of view, the omission of tax avoidance practices can result in injustice and reduce a taxation system's efficiency and effectiveness. Tax avoidance is generally carried out through complex transaction schemes systematically designed and generally only carried out by large corporations. It has led to the perception of injustice, in which large corporations seem to pay fewer taxes. In the end, it can lead to reluctance Taxpayers who else to pay taxes that resulted in the ineffectiveness of the tax system (Wijaya, 2014, 6).

\section{Theory of Deterrent Effect of Tax Audit}

Tax audits conducted by the tax authorities have two types of impacts: direct and indirect. The immediate effect, for example, is additional acceptance. Meanwhile, the indirect impact is the deterrent effect in examinations to prevent tax evasion from potential tax evaders (J. Andreoni et al. 1998, 827). According to the taxpayer's audit track record, the tax authorities detect which taxpayers do not fulfill their penalized obligations. Moreover, the inspection tends to lead to voluntary compliance. The possibility of being investigated and caught committing tax irregularities is a barrier for taxpayers to avoid tax.

\section{METHODOLOGY}

This research object is secondary data obtained from the Indonesian Stock Exchange (BEI) from 2016 to 2018 . The population of this study is companies that have gone public. Their shares have been listed on the IDX from 2016 to the end of 2018. Data regarding tax audits' performance is taken from the Tax Audit Report Application (ALPP) of the Directorate General of Taxes Audit and Collection other data sources relevant to the research method. Several representative samples will be taken for further processing and analysis according to the method chosen. This sample is part of the number and characteristics of the population (Sugiyono, 2011). Sampling was done by purposive sampling, with the following criteria:

1. Companies registered on the IDX and publishing financial reports consistently from 2016 to 2018. The selection of this period is following the period to be tested, namely within three years.

2. Companies listed on the IDX are registered taxpayers at the KPP of Listed Companies.

3. Companies listed on the IDX have undergone regular checks in the period 20162018.

4. Companies that have complete financial data for 2016 to 2018 are required for measuring all variables.

5. Companies in the financial services, construction services, and real estate sectors were excluded from the sample because they have different financial reporting structures and taxation, mostly final.

Secondary sources in this research are annual reports or financial reports of companies that have been listed on the Indonesia Stock Exchange (BEI) from 2016 to 2018 and data on taxpayers of these companies who have undergone tax audits from 
2016 to 2018. Data regarding the financial statements of companies that have been listed on the Indonesia Stock Exchange (IDX) can be obtained from www.idx.co.id. Audit performance data and corporate taxpayers that audited are taken from the Directorate of Audit and Billing (P2) Head Office of the Directorate General of Taxes through the Tax Audit Report Application (ALPP) and other sources deemed appropriate to the research conducted.

To test the hypothesis, the authors used two model regression following key :

a. ETR $_{\text {it }}=\beta_{0}+\beta_{1}$ ENFORCEMENT $_{i t}+\beta_{2}$ SIZE $_{i t}+\beta_{3}$ ROA $_{i t}+\beta_{4}$ LEV $_{i t}+$ $\beta_{5} \mathrm{LIQ}_{\mathrm{it}}+\beta_{6} \mathrm{CASH}_{\mathrm{it}}+\varepsilon_{\mathrm{it}}$

b. ETR $_{\text {it }}=\beta_{\mathrm{o}}+\beta_{1}$ ENFORCEMENT $_{\text {it }}+\beta_{2}$ CONNECTED $_{\text {it }}+$ $\beta_{3}$ ENFORCEMENT $_{\text {it }} \times$ CONNECTED $_{\text {it }}+\varepsilon_{\text {it }}$

The research model adapts Lin, Mills, and Zhang's (2017) research model with several adjustments to data availability and Indonesia's information reporting conditions. Model a and model $\mathrm{b}$ are used to test each hypothesis and in the data analysis process.

\section{RESEARCH RESULT AND DISCUSSION}

The period of the research taken was three years, from 2016 to 2018. Complete financial reports are required for this study to make the data a part of the sample selection criteria. From the purposive sampling results, 102 companies meet the requirements for data processing samples for analysis. Thus, the total data to be used in this study is 306 observational data (company-year).

Table 1 Sample Criteria

\begin{tabular}{|c|c|c|c|}
\hline No. & Criteria & Total & Size \\
\hline 1 & $\begin{array}{l}\text { Companies listed (listing) on the Stock } \\
\text { Exchange from } 2016 \text { to } 2018\end{array}$ & 539 & Company \\
\hline 2 & $\begin{array}{l}\text { Financial services, construction services, and } \\
\text { real estate sector companies (subject to final } \\
\text { tax) }\end{array}$ & (150) & Company \\
\hline 3 & $\begin{array}{l}\text { Companies that are not required to be registered } \\
\text { at the KPP of the Exchange Listed Companies }\end{array}$ & (129) & Company \\
\hline 4 & $\begin{array}{l}\text { Companies that were not continuously subject } \\
\text { to tax audits from } 2016 \text { to } 2018\end{array}$ & (60) & Company \\
\hline 5 & $\begin{array}{l}\text { Companies that do not have complete financial } \\
\text { data for the years } 2016 \text { to } 2018 \text {, including } \\
\text { companies whose profit before tax states a loss } \\
\text { (negative ETR) }\end{array}$ & (98) & Company \\
\hline & Total Samples & 102 & Company \\
\hline & Number of Years & 3 & Year \\
\hline & Company-Year & 306 & Company-Yea \\
\hline
\end{tabular}

Table 2 Variable Descriptive Statistics

\begin{tabular}{lcccccc}
\hline \hline & Mean & Median & Maximum & Minimum & Std. Dev. & Observ. \\
\hline \hline ETR & 0.233609 & 0.236873 & 0.709914 & 0.015191 & 0.087273 & 306 \\
ENFORCEMENT & 0.209439 & 0.201621 & 0.229763 & 0.178633 & 0.050932 & 306 \\
SIZE & 28.47154 & 28.43877 & 32.15098 & 24,52489 & 1.499171 & 306 \\
ROA & 0.080815 & 0.064923 & 0.457885 & -0.02696 & 0.078259 & 306 \\
LEV & 0.544358 & 0.421120 & 1.930943 & 0.075829 & 1.263526 & 306
\end{tabular}




$\begin{array}{lllllll}\text { LIQ } & 2,570563 & 1.796232 & 13.35001 & 0.029217 & 2,099150 & 306 \\ \text { CASH } & 0.136838 & 0.092993 & 0.829215 & 0.001321 & 0.130537 & 306 \\ \text { CONNECTED } & 0.411765 & 0.000000 & 1.000000 & 0.000000 & 0.492959 & 306\end{array}$

Source: Processed with Eviews 9

a. Effective Tax Rate (ETR)

ETR is one of the variables that represent tax avoidance. Based on descriptive statistics, the ETR variable has an average value of 0.233609 . The minimum amount is 0.015191 , and the maximum value is 0.709914 . The average amount of 0.233609 illustrates that companies calculate tax amounting to $23.36 \%$ of profit before tax over three years of the study. Please note that the applicable corporate tax rate in Indonesia is $25 \%$ of profit before tax. A small ETR value compared to the corporate tax rate indicates that company tax avoidance is getting bigger. Conversely, the greater the ETR value, the smaller the tax avoidance, or in other words, the company is more compliant.

b. Tax Audit Effectiveness (ENFORCEMENT)

The ENFORCEMENT variable is an independent variable obtained from the average value of the probability, expertise, and outcome of the examination activity. In descriptive statistics, it can be understood that the average of the variable enforcement of 0.209439 , with a minimum value 0.178633 and a maximum amount, 0.229763 . The average amount of the independent variable of Tax Audit Effectiveness is $20.94 \%$, which is defined as the average of the three factors that make up these variables, namely the possibility of an audit, the tax examiner's expertise, and the results of the tax audit. Details constituent elements Enforcement variables can be explained as follows:

1) Factor Probability of Tax Audit

a) Ratio 1: Number of tax audits compared to the number of reported corporate tax returns.

The average value of the ratio 1 for the three years of the study period was 0.578 , which means $57.8 \%$ of taxpayers' total annual tax returns were audited during the three years of the study period.

b) Ratio 2: Number of Tax Auditor Functional compared to the number of registered Corporate Taxpayers.

The average value of the ratio two during the study period was 0.0789 , which means that the average rate was around 12 taxpayers per 1 examiner.

2) Factors Expertise of Tax Officer

a) Ratio 3: Number of Tax Auditors with E-Audit and Transfer Pricing qualifications compared to the number of tax auditors.

The average value of the ratio three during the study period was 0.0287 , which means $2.87 \%$ of examiners with E-audit and Transfer pricing qualifications.

3) Outcome and Consequence of Tax Audit factors

a) Ratio 4: Total Disbursement of Underpayment Tax Assessment (SKPKB) and administrative sanctions compared to SKPKB Value

The average value of the ratio four over the three years of the study period is 0.2004 , which means that $20.04 \%$ of SKPKB can be disbursed into state revenue.

b) Ratio 5: Total Refund Discrepancy compared to overpayments according to taxpayers.

The average value of the ratio of 5 during the three years of the study period is 0 . 3048. It means that $30.48 \%$ of the overpayment value, according to taxpayers reported in the SPTLB, is not refundable and remains in the state treasury.

c. Company Size (SIZE) 
SIZE is one of the control variables in the central equation of this study. Based on descriptive statistics, the mean value of the SIZE variable is 28.47154 . The minimum amount is 24.52489 , and the maximum value is 32.15098 . The greater the importance of this variable is that its size is getting bigger and has a more significant number of assets. Company size has an average of 28.47154. These companies' average size shows a sample of companies has an average value of total assets of the company amounted to 7.13 trillion rupiahs. It indicates that, on average, the sample companies are classified as large companies because they have a total asset value of more than 1 trillion rupiahs. SIZE is defined from the natural logarithm of total assets for each year.

d. Return on Assets (ROA)

Based on descriptive analysis, the average ROA value is 0.080815 , and the mean value is 0.064923 . The minimum amount is -0.026967 , and the maximum value is 0.457855 . The rate of return of profit before tax when compared to total assets, the average is $8.08 \%$. It shows that during the period 2016 to 2018, the sample companies' average ability to generate profits of $8.08 \%$ of the sample companies' assets was still not maximized in utilizing their assets to create profits.

e. Leverage (LEV)

Based on the descriptive analysis, the average value of LEV is 0.544358 . The minimum amount is 0.075829 , and the maximum value is 1.930943 . LEV is always positive because LEV's calculation, based on total liabilities divided by total assets, is still optimistic. The maximum amount of LEV is quite attentiongrabbing because the value of 1.930943 indicates a company with a liability value almost twice its assets. On average, the companies sampled during the period 2016 to 2018 had solvency, namely the company's ability to complete all its long-term obligations of $54.43 \%$. This figure also indicates that the sample average has Rp.0.52 of debt for every Rp.1.00 of assets owned by the company.

f. Liquidity (LIQ)

The sample companies' liquidity is measured by calculating the ratio between current assets divided by current liabilities. The LIQ variable's average value is 2.570563, with a minimum amount of 0.29217 , and a maximum of 13.35001 . The standard deviation of the sample is 2.099150. It indicates that the average sample company has a current ratio of 2.5 , which means an average example of the company's existing assets amounted to 2.5 times the value of current liabilities so that it can be said to have adequate liquidity.

g. Cash

The sample companies' cash ratios have an average value of 0.136838 with a minimum amount of 0.001321 , a maximum amount of 0.829215 , and a standard deviation of 0.130537 . It shows that, on average, the companies sampled during the period 2016 to 2018 had a total cash ratio of $13.68 \%$ to total assets. The cash ratio that is getting bigger illustrates the company's ability to be better able to pay off its obligations, especially in the obligation to pay tax payments every year.

h. Political Connection (CONNECTED)

Political connection or political connection is a dummy variable based on specific criteria based on Facio (2006). With a minimum value of 0 and a maximum of 1 , the average amount of politically connected sample firms is 0.411765 . Based on the author's data, it can be illustrated that 35 companies have political connections in the research period, namely from 2016 to 2018. Statistically, the descriptive average value was $41.1 \%$. Companies samples 
identified political connections, mostly from BOC, which has links politically, as many as 31 of the 35 companies or by $88 \%$. Political connection in this study is used as a moderating variable that is semi-moderating. It can function both as an independent variable and as a moderating variable in a review, which determines whether these variables can weaken or strengthen the independent variable in the form of tax audit effectiveness.

Hypothesis testing is carried out to prove the hypotheses that have been developed by the author based on relevant theories and the results of previous research. In this study, the authors used a 5\% margin of error. Hypothesis $1\left(\mathrm{H}_{1}\right)$ and hypothesis $2\left(\mathrm{H}_{2}\right)$ were tested respectively, and the appropriate conclusion was taken based on the results of data processing.

a. The Effect of Tax Audit Effectiveness (ENFORCEMENT) on tax avoidance

1) The regression equation formed

The regression model chosen based on this research is the Random Effect Model, as shown in Table 5. This model has fulfilled the classical assumption test required for the Random Effect Model so that Best Linear Unavailable Estimator produces the panel data regression model. Therefore, the regression equation formed is as follows:

ETR $=-0.00638+0.78795 * E^{*}$ NFORCEMENT $i t+0.00287 *$ SIZE $_{i t}-0.01818 * \mathrm{ROA}_{\mathrm{it}}$ $+0.002702 * \mathrm{LEV}_{\mathrm{it}}-0.00095 * \mathrm{LIQ}_{\mathrm{it}}-0.03162 * \mathrm{CASH}_{\mathrm{it}}+\varepsilon_{\mathrm{it}}$

The interpretation of the panel data regression equation, which is formed based on the coefficient value, can be explained as follows:

a) Constant (C) has a regression coefficient value of -0.00638 . It can be interpreted that if all independent variables and control variables are 0 (zero), the ETR value is $\quad-0.00638$.

b) The effectiveness of the Tax Audit (ENFORCEMENT) as an independent variable has a directly proportional relationship to ETR. If the ENFORCEMENT increases by one basis point, then the ETR increases by 0.78795 points, noting that other variables remain.

c) Firm size (SIZE) as part of the control variable has a directly proportional relationship to the ETR where if SIZE increases by one basis point, then the ETR increases by 0.00287 points with the record that other variables are fixed.

d) Return On Asset (ROA) as part of the control variable, negatively relates to ETR. If ROA increases by one basis point, ETR decreases by 0.01818 points, provided that other variables remain. The rate of return on investment in assets is directly proportional to tax avoidance.

e) Leverage (LEV) as part of the control variable has a directly proportional relationship to the ETR where if the LEV increases by one basis point, then the ETR increases to 0.002702 points, provided that other variables remain.

f) Liquidity (LIQ), as part of the control variable, has a negative relationship with ETR. If the LIQ increases by one basis point, the ETR decreases by 0.00095 points, provided that other variables remain.

g) Cash as part of the control variable, has a negative relationship with ETR. If Cash increases by one basis point, then ETR decreases by 0.03162 points, provided that other variables remain.

2) Test the coefficient of determination $\left(R^{2}\right)$

The coefficient of determination shows how far the regression model explains the dependent variable. The coefficient of determination is between zero and one. The 
greater the coefficient of judgment, the stronger the independent variable's ability to explain the dependent variable (Ghozali, 2016). The coefficient of determination in this study is shown in table 3 is 0.240899. It shows the independent variables' ability in the model by $24.09 \%$ explaining the dependent variable. The control variables in the form of company size, ROA, Leverage, Liquidity, and cash are only able to explain $24.09 \%$ of the research dependent variable variation in tax avoidance. In contrast, the rest is explained by other variables that are not included in the study.

Table 3 The value of the coefficient of determination $\left(\mathrm{R}^{2}\right)$

\begin{tabular}{llll}
\hline \hline & & & \\
& & & \\
& & & \\
& & & \\
R-squared & 0.240899 & Mean dependent var & 0.186220 \\
Adjusted R-squared & 0.225666 & SD dependent var & 0.079186 \\
F-statistic & 15.81447 & & \\
Prob (F-statistic) & 0.000000 & \\
& & \\
\hline \hline
\end{tabular}

\section{Source: Processed from Eviews 9}

Ghozali $(2016,95)$ said that the R-squared value has a weakness where there will be a bias towards the data's number of independent variables. As a solution, the Adjusted R-squared value was used.

Based on Table 3, the Adjusted R-squared value is 0.225666. It shows that the resulting regression model has the ability of $22.57 \%$ in explaining the dependent variable. While the rest, namely $77.43 \%$ explained by other variables outside the research. In addition to showing the variable's ability, the Adjusted R-squared value is interpreted to assess whether a model is good or not in the study. The addition or subtraction of independent variables can affect the Adjusted R-squared size.

3) Test of Significance of Individual Parameters (t statistical test)

The T-statistical test is used to measure how far the individual independent variables influence the dependent variable. The t statistical test is also used to see the direction of the independent variable's influence on the dependent variable at a certain level of significance (Ghozali 2016, 97).

This study's t statistical test is used to prove hypothesis $1\left(\mathrm{H}_{1}\right)$ and premise $2\left(\mathrm{H}_{2}\right)$, developed previously. The independent variables in the form of enforcement in conjunction with the five variable control in the way of SIZE, ROA, LEV, LIQ, and will CASH regressed to see its effect on the variable dependent way of ETR. The assessment of the independent variable's influence on the dependent variable uses a significance level of 0.05 . The results of the $t$ statistical test in this study are shown in Table 4.

Table 4 Significance Test Results for Individual Parameters

\begin{tabular}{lllll}
\hline \hline Variable $\quad$ Coefficient & Std. Error & t-Statistic & Prob. \\
\hline \hline
\end{tabular}




$\begin{array}{crrrr}\text { C } & -0.006387 & 0.100502 & -0.063555 & 0.9494 \\ \text { ENFORCEMENT } & 0.787950 & 0.092560 & 8.512874 & 0.0000 \\ \text { SIZE } & 0.002872 & 0.003422 & 0.839141 & 0.4021 \\ \text { ROA } & -0.018189 & 0.067068 & -0.271197 & 0.7864 \\ \text { LEV } & 0.002702 & 0.004104 & 0.658528 & 0.5107 \\ \text { LIQ } & -0.000960 & 0.002041 & -0.470220 & 0.6385 \\ \text { CASH } & -0.031622 & 0.042542 & -0.743312 & 0.4579\end{array}$

Source: Processed from Eviews 9

Hypothesis $1\left(\mathrm{H}_{1}\right)$, which has been developed previously, states that the Tax Audit Effectiveness variable affects tax avoidance. In more detail, it can be interpreted that the more influential the audit activities carried out in Indonesia, the smaller the level of tax avoidance, as indicated by the greater ETR. Based on Table 4, the independent variable's effect partially on the dependent variable is carried out by looking at the t-statistic value and probability value. Each variable's outcome is determined by comparing the t-statistical value with the t-table value and the statistical probability value with a predetermined significance level of 0.05 .

The t-table value is obtained with the help of the Microsoft Excel program using the formula $=$ TINV (probability; deg_freedom). The probability value in this study is 0.05 , and the degree of freedom is obtained by the formula $\mathrm{df}=\mathrm{nk}$ ( $\mathrm{n}=$ number of observations and $\mathrm{k}=$ number of variables). By entering the numbers according to the research in the formula $=\operatorname{TINV}(0.05,298)$ in one of the Microsoft Excel cells, the number is 1.96790. Based on Table 4, the ENFORCEMENT variable has a t-statistic value of 8.512874, more significant than the t-table 1.9679. The significance value is 0.0000 , which is smaller than the significance level of 0.05 , meaning that the $\mathrm{H}_{1}$ hypothesis is accepted. It is because the ENFORCEMENT variable has a significant level of less than 0.05, which is equal to 0.0000 and has a positive effect on ETR so that if ENFORCEMENT increases, then ETR increases. A rising ETR means that the level of tax avoidance has decreased.

b. The Effect of Political Connection (CONNECTED) on the relationship between Tax Audit Effectiveness (ENFORCEMENT) on Tax Avoidance

1) Political Connection moderating variable regression model

The regression model used in determining the effect of political connections, as mentioned in chapter III is as follows:

$$
\begin{aligned}
\text { ETR }_{\text {it }}=\beta_{\mathrm{o}} & +\beta_{1} \text { ENFORCEMENT }_{\text {it }}+\beta_{2} \text { CONNECTED }_{i t} \\
& +\beta_{3} \text { ENFORCEMENT }_{i t} \times \text { CONNECTED }_{i t}+\varepsilon_{i t}
\end{aligned}
$$

There is an additional variable used in the regression calculation with the moderating variable in the equation model used, namely the multiplication of the audit effectiveness variable and the political connection variable (ENFORCEMENT X CONNECTED). By including these variables, it can be analyzed whether the moderating variable in the form of political connections will strengthen or weaken the relationship between the effectiveness of tax audits and tax avoidance.

2) Significance Test of Individual Parameters (t statistical test)

The regression results clearly show that the ENFORCEMENT variable individually provides a coefficient value of 0.826 with a significant probability of 0.001 . The CONNECTED variable provides a coefficient value of 0.084 , with a substantial chance of 0.001 . It can be concluded that these two variables affect 
ETR. The moderating variable ENFORCEMENT X CONNECTED was also notable, with a significant probability of 0.001 far below 0.05 . The regression results of the $t$ statistical test can be seen in table 5 .

Table 5 Significance Test of Individual Parameters

\begin{tabular}{|c|c|c|c|c|c|c|c|}
\hline \multirow[t]{2}{*}{ Model } & \multicolumn{2}{|c|}{$\begin{array}{c}\text { Unstandardiz } \\
\text { ed } \\
\text { Coefficients }\end{array}$} & \multirow{2}{*}{$\begin{array}{c}\begin{array}{c}\text { Standardiz } \\
\text { ed } \\
\text { Coefficien } \\
\text { ts }\end{array} \\
\text { Beta }\end{array}$} & \multirow[t]{2}{*}{$\mathrm{t}$} & \multirow[t]{2}{*}{ Sig. } & \multicolumn{2}{|c|}{$\begin{array}{l}\text { Collinearity } \\
\text { Statistics }\end{array}$} \\
\hline & B & $\begin{array}{l}\text { Std. } \\
\text { Error }\end{array}$ & & & & $\begin{array}{c}\text { Toleran } \\
\text { ce }\end{array}$ & VIF \\
\hline 1 (Constant) & 0.063 & 0.018 & & $\begin{array}{c}3,46 \\
8\end{array}$ & $\begin{array}{c}0.00 \\
1\end{array}$ & & \\
\hline ENFORCEMENT & 0.826 & 0.085 & 0.482 & $\begin{array}{c}9,72 \\
1\end{array}$ & $\begin{array}{c}0,00 \\
0\end{array}$ & 0.972 & $\begin{array}{c}1,02 \\
9\end{array}$ \\
\hline CONNECTED & 0.084 & 0.025 & 0.475 & $\begin{array}{c}3,40 \\
5\end{array}$ & $\begin{array}{c}0.00 \\
1\end{array}$ & 0.123 & $\begin{array}{c}8,13 \\
2\end{array}$ \\
\hline $\begin{array}{l}\text { ENFORCEMENTXCONNEC } \\
\text { TED }\end{array}$ & 0.362 & 0.109 & 0.465 & $\begin{array}{c}3,32 \\
3\end{array}$ & $\begin{array}{c}0.00 \\
1\end{array}$ & 0.122 & $\begin{array}{c}8,21 \\
5\end{array}$ \\
\hline
\end{tabular}

a. Dependent Variable: ETR

Source: Processed from SPSS 23

3) Simultaneous Significance Test (Test F)

The F statistical test shows whether all the independent variables included in the model have a joint influence on the dependent variable (Ghozali, 2016, 98). To assess the effect of variables simultaneously, it is done by comparing the Fstatistic value with the f-table value. If the F-statistic value is greater than the $\mathrm{f}$ table value, it can be concluded that the independent variables jointly affect the dependent variable. Meanwhile, the simultaneous assessment of the effect's significance is carried out by comparing F's probability value with the significance level used at $5 \%$.

The results of the F statistical test are presented in table 6 . Based on table 6 , it is known that the F-statistic is 38.854. To find out, the f-table value is calculated manually using the help of the Microsoft Excel program by entering the formula = FINV $(0.05,2.302)$. The explanation of the procedure $=$ FINV $(0.05,2.302)$ is 0.05 in the level of significance, 2 is the number of variables $(n=3)$ minus 1 , and 302 is the result of the number of observations minus the number of variables minus 1 (the number of words 306). From these calculations, the value of $\mathrm{f}$ table 3.0256, is obtained. The F-statistic value is more excellent than the f table, and the significance level of 0.000 is far below 0.05. It means that the independent variables ENFORCEMENT, CONNECTED, and ENFORCEMENT $\mathrm{X}$ CONNECTED or simultaneously affect ETR. The results of the $f$ test for the moderating variable are shown in table 6 .

Table 6 Simultaneous Significance Test Results

ANOVA $^{\mathrm{a}}$

\begin{tabular}{|c|c|c|c|c|c|}
\hline Model & Sum of Squares & $\mathrm{df}$ & Mean Square & $\mathrm{F}$ & Sig. \\
\hline Regression & 0.647 & 3 & 0.216 & 38,854 & $\begin{array}{c}0,000 \\
\mathrm{~b}\end{array}$ \\
\hline Residual & 1,676 & 302 & 0.006 & & \\
\hline
\end{tabular}




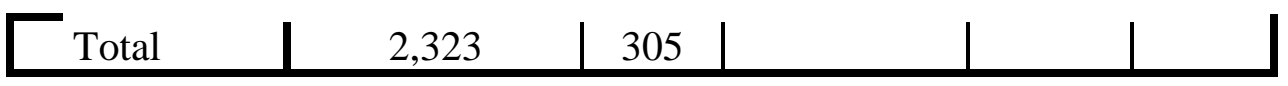

a. Dependent Variable: ETR

b. Predictors: (Constant), ENFORCEMENTxCONNECTED, ENFORCEMENT, CONNECTED

Source: Processed from SPSS 23

4) Determination Coefficient Test $\left(\mathrm{R}^{2}\right)$

Display output regression shows the value adjusted $R^{2}$ at 0.271 , which means the variability can be explained by the variable ETR Enforcement, Connected, and Enforcement X Connected approximately $27.1 \%$, and other variables outside the model explain the remaining $72.9 \%$. So it can be concluded that the model is not good enough. The adjusted value $\mathrm{R}^{2}$ can be seen in table 7 .

Value adjusted by $27.1 \%$ illustrates an increase of the value adjusted before moderated by the variable equals $22.56 \%$ political, which means reconciling variable political connections strengthens the relationship between tax audits' effectiveness with tax evasion.

Table 7 Determination Coefficient Test $\left(\mathrm{R}^{2}\right)$ Model Summary

\begin{tabular}{|c|c|c|c|c|}
\hline Model & $\mathrm{R}$ & R Square & $\begin{array}{c}\text { Adjusted R } \\
\text { Square }\end{array}$ & $\begin{array}{c}\text { Std. Error of } \\
\text { the Estimate }\end{array}$ \\
\hline 1 & $0.528^{\mathrm{a}}$ & 0.278 & 0.271 & 0.07449915 \\
\hline
\end{tabular}

Source: Processed from SPSS 23

This study aims to determine the relationship between audit activities' effectiveness on tax avoidance with the moderating variable of political connections. Based on Lin, Mills, and Zhang's (2017) 's research, the authors researched the necessary adjustments to be applied in Indonesia. This study also uses control variables, including company size, return on assets, leverage, liquidity, and cash. The data used in this study is panel data of publicly traded companies from 2016 to 2018 or also known as panel data. In this study, the authors used companies registered in the Tax Office in the Exchange from 2016 to 2018. The author selects the sample by using the purposive sampling method based on existing theories and the availability of supporting data that can be used in this study.

1. Effect of Tax Audit Effectiveness on Tax Avoidance

Based on Table 4, it can be seen that the ENFORCEMENT variable has a tstatistic value of 8.512874 , more significant than the 1.9679 t-table. The significance value $\quad 0.0000$, which is smaller than the 0.05 significance level, means that the tax audit effectiveness variable significantly affects ETR, a measure of tax avoidance in this study. Furthermore, the tax audit coefficient, which has a positive value on ETR, shows that the more effective a tax audit is, the ETR will also increase, which means the company is more compliant. It proves that hypothesis $1\left(\mathrm{H}_{1}\right)$, which states that tax audits' effectiveness affects tax avoidance, is accepted.

This study's results are consistent with research from Lin, Mills, and Zhang $(2017,31)$ conducted in China entitled " Do Political Connection Weaken Tax Enforcement Effectiveness? " where the effectiveness of tax audits was obtained from tax inspection macro data affects tax avoidance. This study uses data similar to the data used in the research of Lin, Mills, and Zhang (2017), 
namely by using the probability of a company being examined (likelihood of). tax audit), factor membership of inspectors tax (expertise of tax officer), and also factor test results (outcome and consequence of tax audit) as determinants of the effectiveness of tax audits in Indonesia, but research is still limited to firms to enter the market (go public).

The probability of conducting a tax audit at the KPP of the Listed Companies (PMB) based on data from the Directorate of Audit and Billing DGT for three years, the study sample had an average of $57.8 \%$. This figure is higher than the ratio of the probability of being audited by corporate taxpayers throughout Indonesia, which is 20\% (DGT Annual Report 2016). The higher likelihood of tax audit will affect the tendency of taxpayers to be more compliant. It is supported by research conducted by J Alm (1992, 36) with experimental research on taxpayer behavior related to the probability of audits. The investigation concluded that taxpayers would be less likely to comply if the likelihood of conducting a tax audit was low.

Factors expertise of tax inspectors and inspection results factor into two things that need more attention DGT in evaluating the effectiveness of tax audits that have been executed. Competence tax inspectors in KPP PMB, particularly concerning e-audit and transaction examination of transfer pricing, are very low. From 2016 to 2018 , only $2.88 \%$ of tax auditors had this competence. In other words, only 1 in 35 tax auditors at KPP PMB had the competence needed in the audit activities of going public companies. The results (outcome) of the tax audit also cannot be said to be optimal. Disbursement of Underpaid Tax Decree (SKPKB) at KPP PMB is in the range of 0.2004 each year, which means that only $20 \%$ of SKPKB can become state revenue the current year, while the rest is not yet collected.

The contribution of probability, expertise, and outcome factors in this study resulted in the ENFORCEMENT variable with a $22.57 \%$ determination coefficient. However, to optimize tax policies to minimize tax avoidance, several things need to be underlined. Procedures to increase the probability, expertise, and outcomes cannot automatically increase compliance. Research from Hoopes, Mescall, and Pittman (2012), which discusses the determinants of corporate tax avoidance by including the role of Internal Revenue Service (IRS) supervision, states that optimizing tax policy is not as simple as improving audit performance. It is because the tax authorities need to consider allocating resources in carrying out their duties and functions. Audit activities are costly activities, so it requires a combination of policies between power and trust, such as policies in terms of sanctions, tax rates, knowledge of taxes, norms, and fairness in tax collection (E Kirchler 2008, 214-219).

2. Political Connection (Political Connection) strengthens the effect of Tax Audit Effectiveness on Tax Avoidance

Based on the table, it can be seen that adjusted $\mathrm{R}^{2}$ is 0.271 , which means that ETR variability can be explained by the ENFORCEMENT, CONNECTED, and ENFORCEMENT $X$ CONNECTED variables around 27.1\%. Other variables explain the remaining $72.9 \%$ outside of this research model. Value adjusted $R^{2}$ by $27.1 \%$ illustrates an increase of the value adjusted $R^{2}$ before it is moderated by political connections variable equal to $22.57 \%$, which means a moderating variable political connection strengthens the relationship between tax audits' effectiveness with tax evasion. Thus, hypothesis $2\left(\mathrm{H}_{2}\right)$, which states that political connections weaken tax audit effectiveness on tax avoidance, is rejected. 
This study's results differ from research conducted in China by Lin, Mills, and Zhang (2017), used as a reference journal. This research proves that companies connected politically tend to be more compliant when the tax audits conducted by the DGT are more effective.

One of the factors causing the differences in research results is the difference in China and Indonesia's conditions and differences in research data. In the socialist Chinese government system, the politics of a person inside and outside the government is powerful ( $\mathrm{Li}$ et al. 2006, 1). The Communist Party in China is mighty, and the government still has absolute power in regulated sectors of the economy that are considered essential, primarily through state-owned enterprises. According to Li et al. (2006), in the absence of an opposition party and political relations that tend to be corrupt, government control becomes very large. One of them affects the competition for private companies that have begun recruiting active government officials and former members of the People's Congress to become company executives to compete with state-owned companies ( $\mathrm{Li}$ et al. 2006, 3). Besides, there are compositional differences in the structure of political connections between companies in China and Indonesia. Lin, Mills, and Zhang's research (2017) explains that $34 \%$ of China's political relationships are company executives (board of directors). In this study, $88 \%$ of sample companies that are politically connected hold positions as the commissioners' board.

Indonesia itself has a more democratic system of government compared to China. It is reinforced by a system of checks and balances that results in power not being concentrated in one place while promoting transparency and accountability. The public sector is required to guarantee good governance in carrying out its duties and functions (Kaihatu, 2006). On the other hand, demands for transparency in implementing good corporate governance in the private sector are an essential priority for stakeholders. Based on the 2016 Corporate Governance Report issued by the Asian Corporate Governance Association (ACGA) in collaboration with CLSA Limited, it shows that Indonesia is in third place in terms of company management's independence in implementing information transparency, while China is in ninth place. The data shows that Indonesia is better in terms of the clarity of information provided by a company. In connection with the companies' organizational structure in the private sector, Ujiyantho and Scout (2007) highlight the commissioner's role in an enterprise in earnings management in the company went public. The study reveals that the board of commissioners can act as a mediator in disputes between managers and supervise management policies to implement the monitoring function to create companies implementing the principles of good corporate governance. In another study, Rusmin, Evans, and Hossain (2012), comparing the performance of politically connected companies before and after the reform period in Indonesia, explained that after the reform period, political ties within and outside the government were not as strong as when the New Order regime was in power. The study also states that political connections and corporate good corporate governance positively correlate with the company's value.

The results of this study explain that political connections strengthen the influence of tax audit effectiveness on tax avoidance. $88 \%$ of the political ties that occur in the sample companies are on the board of commissioners. The results of this study can be seen in agency theory. In agency theory, there is a phenomenon of the agency problem. The agency problem arises from the gap between the interests of shareholders as owners and management as managers. Jensen and Meckling $(1976,45)$ say that what can be 
done to reduce managers' chance to take actions detrimental to outside investors is two ways: monitoring and limiting their actions (bonding). The activities that will reduce the likelihood of irregularities by the manager, one way to avoid taxes, so that the company's value will increase.

But on the other hand, both will come at a cost. One of the monitoring mechanisms is the formation of a board of commissioners. According to Article 1 number 6 of Law number 40 of 2007 concerning Limited Liability Companies, the board of commissioners is an organ of the company tasked with conducting general and/or special supervision following the articles of association and providing advice to the board of directors. In principle, the role of commissioners is to supervise and give advice to the directors. The part of the board of commissioners is to oversee the board of directors or directors' actions. The board of commissioners is responsible for the company's supervision as stipulated in Article 108, paragraph 1 of the Limited Liability Company Law. It states that the board of commissioners supervises management policies, general management, both regarding the company and its business and provides advice to the board of directors. When company commissioners' duties and functions are carried out properly, the company should not be too aggressive in avoiding taxes. Regarding tax audit activities, this study's results indicate that politically connected companies can increase audit activities' effectiveness, one of which is through cooperative action by the board of directors and the board of commissioners.

\section{CONCLUSION}

Factors tax audit effectiveness significantly affect tax evasion for companies registered in the LTO company in the stock exchange from 2016 to 2018. It means that the more influential the tax audit activity is, the smaller the level of tax avoidance, as indicated by the greater Effective Tax Rate (ETR). The company's political connections-company registered in LTO company exits in the stock exchange reinforce the effect of tax audits against tax evasion. The next researcher is expected that the sample selection will not only be carried out at companies listed on the Indonesia Stock Exchange (IDX). These are taxpayers at the KPP of the Listed Companies and taxpayers in the work area of the Special DJP Jakarta Regional Office as a whole and the DGT Regional Office for Large Taxpayers, to provide a more comprehensive picture of the data on financial statements of companies listed on the IDX.

\section{REFERENCES}

\section{A. Textbooks / Magazines / Periodic Journals and Electronic Formats}

Allingham, M., A. Sandmo. 1972. Income Tax Evasion: A Theoretical Analysis. Journal of Public Economics 1: 323-328.

Alm, J., McClelland, GH, and Schulze, WD, 1992. Rev Do People Pay Taxes ?. Journal of Public Economics, 48 (1), 21-38.

Andreoni, J., Erard, B., and Feinstein, J. 1998. Tax compliance. Journal of economic literature, 36 (2), 818-860.

Arnold, B., 2008. A Comparison of Statutory General Anti-Avoidance Rules and Judicial General Anti-Avoidance Doctrines as a Means of Controlling Tax Avoidance: Which is Better? In PH John Avery Jones, Comparative Perspectives on Revenue Law (p. 1). Cambridge: Cambridge University Press.

Arnold, J. (2008). Do Tax Structures Affect Aggregate Economic Growth ?. 
Armstrong, C., Blouin, J., and Larcker, D. 2012. The incentives for tax planning. Journal of Accounting and Economics 53: 391-411.

Armstrong, C., Blouin, J., Jagolinzer, and A., Larcker, D. 2013. Corporate Governance, Incentives, and Tax Avoidance. Rock Center for Corporate Governance at Stanford University Working Paper (136).

Birskyte, L., 2013. Effects of Tax Auditing: Does The Deterrent Deter ?. Research Journal of Economics, Business, and ICT 8

Budiman, J., 2012. The Influence of Executive Character Against Tax Avoidance (Doctoral dissertation, Gadjah Mada University).

Chen, S., Chen, X., Cheng, Q. and Shevlin, T. 2010. Are family firms more tax aggressive than non-family firms? Journal of Financial Economics 95: 4161.

Chen, D., Li, O., and Xin, F. 2013. Five-year plans, China finance, and their consequences. " Unpublished paper, Nanjing University. Available at: http://papers.ssrn.com/sol3/papers.cfm?abstract_id=2259388

Cheng, A., Huang, H., Ying, I., and Stanfield, J. 2012. The effect of hedge fund activism on corporate tax avoidance? The Accounting Review 87: 14931526.

Debacker, J., Heim, BT, Tran, A., and Yuskavage, A. 2013. Legal enforcement and corporate behavior: An analysis of tax aggressiveness after an audit. Available at: https: //papers.ssrn.com/sol3/papers.cfm? Abstract_id $=2262586$

Dechow, P., Sloan, R., and Sweeney, A., 1995. Detecting earnings management. The Accounting Review 70: 193-225.

Dechow, P., Ge, P., and Schrand, G. 2010. Understanding earnings quality: a review of the proxies, their determinants, and their consequences. Journal of Accounting and Economics 50: 344-401. 55

Desai, MA, 2005. The Degradation of Reported Corporate Profits. Journal of Economic Perspectives, 19 (4), 171_192.https: //doi.org/10.1257/089533005775196705

Desai, M., Dharmapala, D. 2006. Corporate tax avoidance and high-powered incentives. Journal of Financial Economics 79: 145-179.

Desai, M., Dyck, A., and Zingales, L. 2007. Theft and taxes. Journal of Financial Economics 84: 591-623.

Dyreng, SD, Hanlon, M., and Maydew, EL, 2008. Long-run corporate tax avoidance. The accounting review, 83 (1), 61-82.

Dyreng, SD, Hanlon, M., and Maydew, EL, 2010. The effects of executives on corporate tax avoidance. The Accounting Review, 85 (4), 1163-1189.

Faccio, M., 2006. Politically connected firms. American economic review, 96 (1), 369- 386.

Faccio, M., Masulis, RW, and McConnell, J., 2006. Political connections and corporate bailouts. The Journal of Finance, 61 (6), 2597-2635.

Frank, MM, Lynch, LJ, and Rego, SO 2009. Tax reporting aggressiveness and its relation to aggressive financial reporting. In Accounting Review (Vol. 84, pp. 467-496). http://doi.org/10.2308/accr.2009.84.2.467

Ghozali, Imam. 2016. Multivariate Analysis Application with IBM SPSS 23 Update PLS Regression Edition 8. Semarang: Diponegoro University Publisher Agency.

Graham, JR, Hanlon, M., Shevlin, T., and Shroff, N. 2014. Incentives for tax planning and avoidance: Evidence from the field. Accounting Review 89: 9911023.

Gujarati, Damonar N., and Dawn C. Porter. 2009. Basic Econometrics (5th Edition). New York: McGraw-Hill / Irwin. 
Hanlon, M., S. Heitzman. 2010. A review of tax research. Journal of Accounting and Economics 50: 127-178.

Hanlon, M., Hoopes, J., and Shroff, N. 2014. The effect of tax authority monitoring and enforcement on financial reporting quality. Journal of the American Taxation Association, forthcoming.

Hoopes, J., Mescall, D., and Pittman, J. 2012. Do IRS audits deter corporate tax avoidance? The Accounting Review 87: 1603-1639.

Hutagaol, J., Winarno, WW, and Pradipta, A., 2007. Strategies to Improve Taxpayer Compliance. Journal of Accountability, 6 (2), 186-193.

James, S., Alley, C., 2002. Tax compliance, self-assessment, and tax administration.

James, S., 1999. The future international tax environment and European tax harmonization: a personal view. European Accounting Review, 8 (4), 731-747.

Jones, J., 1991. Earnings management during import relief investigations. Journal of Accounting Research 29: 193-228.

Jensen, MC, and Meckling, WH, 1976. Theory of the firm: Managerial behavior, agency costs, and ownership structure. Journal of financial economics, 3 (4), 305-360.

Kaihatu, TS 2006. Good corporate governance and its application in Indonesia. Journal of Management and Entrepreneurship, 8 (1), 1-9. Kim, CF, Zhang, L. 2016. Corporate political connections and tax aggressiveness. Contemporary Accounting Research, 33 (1), 78-114.

Kirchler, E., Hoelzl, E., and Wahl, I. 2008. Enforced versus voluntary tax compliance: The " slippery slope " framework. Journal of Economic Psychology, 29, 210225.

Lee, B., Dobiyanski, A., and Minton, S. 2015. Theories and Empirical Proxies for Corporate Tax Avoidance. Journal of Applied Business And Economics Vol. 17

Lennox. C. Li. W., Pittman, J., and Wang, Z. 2015. The Determinants and Consequences of Tax Audits: Some Evidence from China. Journal of Economic Literature

Leuz, C., Oberholzer-Gee, F. 2006. Political relationships, global financing, and corporate transparency: Evidence from Indonesia. Journal of financial economics, 81 (2), 411-439.

Li, Y. 2014. Tax-induced earnings management, auditor conservatism, and tax enforcement (Master's thesis, Lingnan University, Hong Kong). Retrieved from http://commons.ln.edu.hk/acct_etd/17

Lin, KZ, Mills, LF, Zhang, F., and Li, Y. 2017. Do Political Connections Weaken Tax Enforcement Effectiveness ?. Contemporary Accounting Research.

Lin, K., Mills, L., F. \& Zhang, F. 2014. The tradeoffs between tax savings and financial reporting costs: Public versus private firms in China. The Journal of the American Taxation Association. Forthcoming.

Mardiasmo. 2011. Taxation. Revised Edition. CV. Andi Offset. Yogyakarta

McGuire, ST, Omer, TC, and Wang, D., 2012. Tax avoidance: Does tax-specific industry expertise make a difference ?. The Accounting Review, 87 (3), 9751003.

Mills, L., 1998. Book-tax differences and internal revenue service adjustments. Journal of Accounting Research 36: 343-356.

Mills, L., Erickson, M., and Maydew, E., 1998. Investments in tax planning. The Journal of the American Taxation Association 20: 1-20. 
Nachrowi, Nachrowi., D., and Usman, H. 2006. Popular and Practical Econometric Approaches to Economic and Financial Analysis. Jakarta: FE-UI Publishing Institute.

Richardson, G., Taylor, G., and Lanis, R., 2013. The impact of the board of director oversight characteristics on corporate tax aggressiveness: An empirical analysis. Journal of Accounting and Public Policy, 32 (3), 68-88. http://doi.org/10.1016/j.jaccpubpol.2013.02.004

Robinson, J., Sikes, S., Weaver, C., 2010. Performance Measurement of Corporate Tax Departments. The Accounting Review 85: 1035-1064

Slemrod, J., 2007. Cheating ourselves: the economics of tax evasion. Journal of Economic Perspectives 21: 25-48.

Sugiyono. 2017. Quantitative, qualitative, and $R \& D$ Research Methods. Bandung: Alfabeta, 90.

Sugiyono. 2015. Easy Ways to Arrange: Thesis, Thesis, and Dissertation. Bandung: Alfabeta Publisher

Ujiyantho, MA, and Pramuka, BA, 2007. Corporate governance mechanisms, earnings management, and financial performance. National Symposium on Accounting X, 10 (6). Waluyo and Wirawan B. Ilyas. 2013. Indonesian Taxation. Jakarta: Salemba.

Wahyudi, D., 2012. The Influence of Good Corporate Governance and Tax Audit on Tax Avoidance. Tax Training Center.

Wijaya, Ibnu. 2014. Knowing Tax Avoidance, Available at https://www.linkedin.com/pulse/20140726022710-57653111- to recognize -taxavoidance-tax-avoidance? Trk = prof-post

Zhu, YB, Liu, X., and Wang, Z., 2010. Abatement effect of carbon tax and its impacts on the economy in China. China Soft Sci, 4, 1-9.

\section{B. Public Documents and Resources -s umber Other}

Republic of Indonesia. 2007. Law of the Republic of Indonesia Number 28 of 2007 concerning the Third Amendment to Law Number 6 of 1983 concerning General Provisions and Tax Procedures. State Gazette of the Republic of Indonesia of 2007, No. 85 Cabinet Secretariat of the Republic of Indonesia. Jakarta.

Republic of Indonesia. 1983. Law of the Republic of Indonesia Number 6 of 1983 concerning General Provisions and Tax Procedures. State Gazette of the Republic of Indonesia Year 1983, No. 49 State Secretary of the Republic of Indonesia. Jakarta.

Republic of Indonesia. 2015. Regulation of the Minister of Finance of the Republic of Indonesia Number 184 / PMK.03 / 2015 concerning Amendments to the Regulation of the Minister of Finance Number 17 / PMK.03 / 2013 concerning Audit Procedures. State Gazette of the Republic of Indonesia of 2015, No. 1468. Secretariat of the Cabinet of the Republic of Indonesia. Jakarta.

Republic of Indonesia. 2013. Regulation of the Minister of Finance of the Republic of Indonesia Number 17 / PMK.03 / 2013 concerning Audit Procedures. State Gazette of the Republic of Indonesia of 2013, No. 47 Secretariat of the Cabinet of the Republic of Indonesia. Jakarta. 
Republic of Indonesia. 2017. Circular of the Director-General of Taxes Number SE- 11 / PJ / 2017 Concerning About. Plans, Strategies, and Measurement of Audit Performance in 2017. Ministry of Finance of the Republic of Indonesia. Jakarta

Republic of Indonesia. 2016. Letter Circular Director General of Tax No. SE-0 6 / PJ / 2016 T Entang Examination Policy. Directorate General of Taxes. Ministry of Finance of the Republic of Indonesia. Jakarta 